\title{
The Effect Of Financial Ratios On Changes In Profit In Mining Companies Listed On The Indonesia Stock Exchange
}

\begin{abstract}
Andreas W. P. Sinurat
Department of Accounting, Univesity Of North Sumatra, Indonesia

ABSTRACT

The purpose of this study was to determine the effect of the company's financial ratios are empirically, either partially or simultaneously to changes in earnings. Financial ratios tested is Current Ratio (CR), Working Capital to Total Assets (WCTA), Debt to Total Equity Ratio (DER), and Profit Margin (PM). This research is a kind of replication, causal research to previous research with the study population is a mining company listed on the Indonesia Stock Exchange during the period of 2007-2011. The sample selection method and purposive sampling of 31 companies listed in Indonesia Stock Securities acquired 11 companies sampled. The data used are secondary data. This study analyzes the relationship between CR, WCTA, DER, PM and changes in earnings. The statistical method used was multiple linear regression and performed classical assumption first. These results indicate that the variables $C R$, WCTA, DER, and PM simultaneously significant effect on changes in earnings. Partial test shows that the variables CR, WCTA and PM significant impact on earnings changes. Other variables that DER no significant effect on changes in earnings.
\end{abstract}

This is an open access article under the CC BY-NC license.

\section{Corresponding Author:}

Andreas W. P. Sinurat, Department of Accounting, University Of North Sumatara, Indonesa, Jl. Dr. Mansur No. 9 Padang Bulan, Kec. Medan Baru, Kota Medan 20222.

Email: andreassinurat@gmail.com

\section{INTRODUCTION}

Financial ratios are often used to measure the strengths or weaknesses faced by companies in the financial sector which are basically not only useful for the company's internal interests, but also for external parties. In addition, financial ratios can be used as an early warning system against a decline in financial conditions to make decisions or balances about what the company will achieve and how the prospects will be faced in the future. The predictive power of financial ratios in predicting earnings so far is indeed very useful in assessing the company's performance in the future. The predictive power of financial ratios was found differently by several researchers. Researchers who say that the Current Ratio has a significant effect on earnings changes are Meriewaty and Setyani (2005) using a sample of companies in the food and beverages industry listed on the JSE and Eka Khairunnisa Zul (2009) with a sample of manufacturing companies listed on the Indonesian stock exchange. While the researchers who said it had no effect were Eko Bastian Damanik (2010) with a sample of manufacturing companies in the consumer goods industry sector listed on the BEI and Roselina Pakpahan (2011) with a sample of automotive companies listed on the Indonesian stock exchange. 
Research on the effect of Working Capital to Total Assets on earnings changes was conducted by Eka Khairunnisa Zul (2009) with a sample of manufacturing companies listed on the Indonesian stock exchange. While the research that suggests that there is no effect between Working Capital to Total Assets is the research of Meriewaty and Setyani (2005). Research by Eka Khairunnisa Zul (2009) which uses a sample of manufacturing companies listed on the BEI shows that there is an effect of the Debt to Equity Ratio on changes in earnings. Meanwhile, research by Roselina Pakpahan (2011) states that there is no influence between the Debt to Equity Ratio on changes in earnings.

Hestina Wahyu Dewanti (2009) conducted a study on the effect of profit margin on profit margin changes with a sample of foreign exchange bank companies and non foreign exchange banks showing an influence between the two variables. Meanwhile, the researcher who said that it had no effect was Muhamad Sarifudin (2005) with a sample of banking companies listed on the JSE. This study is intended to carry out further testing of empirical findings regarding financial ratios, especially regarding their usefulness in predicting future earnings. The reason for choosing accounting profit is because profit reflects the company's performance, from the size of the profit it can be seen whether the company has a good performance or not. If financial ratios can be used as a predictor of future earnings changes, this finding is quite useful knowledge for users of financial statements who are in real terms, or have potential interest in a company. On the other hand, if the ratio is not significant enough to predict future earnings changes, the results of this study will strengthen the evidence regarding the inconsistency of previous empirical findings.

\section{RESEARCH METHOD}

\subsection{Analysis Techniques and Hypothesis Testing}

In conducting the analysis and hypothesis testing, the procedures carried out were assisted by using computer programs, namely SPSS 18.0 for Windows and Microsoft Excel 2007.

\section{a. Analysis Techniques} analysis.

The analytical technique used in testing the hypothesis in this study is multiple regression

This analysis was conducted to determine whether or not there is an effect of CR, WCTA, $D E R$, and PM as independent variables on changes in earnings as the dependent variable.

1) Data Normality Test. The purpose of the normality test is to find out whether in the regression model the confounding or residual variables have a normal distribution. This test is useful for the early stages in the method of selecting data analysis. If the data is normal, then parametric statistics are used, and if the data is not normal, then nonparametric statistics are used or do treatment so that the data is normal. The researcher used the Kolmogorov Smirnov test to test the normality of the data. If the probability $>0.05$ then the data distribution is normal and multiple regression can be used. In addition, the normality test can also be performed by analyzing the normal probability plot graph and histogram graph.

2) Multicollinearity Test. Multicollinearity test was conducted to determine whether the independent variables contain a correlation or not. The results of the multicollinearity test can be seen based on the Variance Inflation Factor (VIF) value.

3) Heteroscedasticity Test. The purpose of this heteroscedasticity test is to test whether in a regression model there is an inequality of variance from the residuals from one observation to another observation. If the variance of the residuals from one observation to another is constant, it is called homoscedasticity (Erlina, 2008). Detection of the presence or absence of heteroscedasticity symptoms is by looking at the presence or absence of certain patterns. If it forms a certain pattern, then heteroscedasticity has occurred.

4) Auto Correlation Test. Uji autokorelasi digunakan untuk mengetahui apakah terjadi korelasi antar anggota sampel yang diurutkan berdasarkan waktu. Konsekuensi dari adanya autokorelasi dalam model regresi adalah varian sampel tidak dapat menggambarkan varian populasinya. Diagnosa adanya autokorelasi dilakukan melalui pengujian terhadap nilai uji Durbin Watson (uji DW). 


\section{RESULTS AND DISCUSSIONS}

\subsection{Analisis dan Pengujian Hipotesis}

Sebelum melakukan pengujian hipotesis peneliti terlebih dahulu melakukan perhitungan rasiorasio pada variabel independen dan melakukan perhitungan perubahan laba pada masing-masing perusahaan sebagai variabel dependen.

\section{a. Analisis Deskriptif}

Descriptive analysis was carried out in order to provide an overview of the variables used in the study. This study uses four independent variables which aim to determine the relationship between the current ratio (CR), working capital to total assets (WCTA), debt to equity ratio (DER) and profit margin (PM) to changes in earnings. The dependent variable in this study uses changes in earnings. Descriptive variables on the data were carried out for five years, so that the total number of observed data was 55 samples.

Based on the results of data processing with the help of SPSS (Statistical Product and Service Solution) version 17.0, the calculation results are obtained as follows:

Table 1. Descriptive Statistics

Descriptive Statistics

\begin{tabular}{lccc}
\hline & mean & Std. Deviation & $\mathrm{N}$ \\
\hline PERUB.PROFIT & 1.356737 & 2.4334373 & 55 \\
CR & 2.621609 & 2.2142361 & 55 \\
WCTA & .211962 & .2506141 & 55 \\
DER & 2.132564 & 2.9626474 & 55 \\
PM & .175510 & .2074838 & 55 \\
\hline \multicolumn{2}{l}{ Source: Data processed by the author }
\end{tabular}

From table 1 above, it is known that the number of samples used in this study were 55 samples. In addition, it is known that the average change in profit is 1.356737 with a standard deviation of 2.4334373. CR (Current Ratio) has an average of 2.621609 with a standard deviation of 2.2142361. WCTA (Working Capital to Total Assets) has an average of 0.211962 with a standard deviation of 0.2506141 . DER (Debt to Equity Ratio) has an average of 2.132564 with a standard deviation of 2.9626474. PM (Profit Margin) has an average of 0.175510 with a standard deviation of 0.2074838 .

The average value listed above can be used as an indication that the value of each ratio or variable produced is greater than the average value, it can be said that the company's condition is good. And vice versa if the value of each ratio or the resulting variable is smaller than the average value, it can be said that the condition of the company is in a bad condition. So that the management needs to do an evaluation in the year concerned to get a solution so that the company can return to good.

\section{b. Multiple Regression Analysis}

Multiple regression analysis aims to determine whether or not there is an effect of the independent variables, namely Current Ratio (LN_CR), Working Capital To Total Assets (LN_WCTA), Debt To Equity Ratio (LN_DER), and Profit Margin (LN_PM) on the dependent variable Changes in Profit.

Dengan menggunakan SPSS 17.0 data diolah untuk dapat menunjukkan adanya pengaruh atau tidak antara variabel independen (current ratio, working capital to total assets, debt to equity ratio, profit margin) dengan variabel dependen (perubahan laba). Berikut ini adalah hasil analisis regresi berganda:

Tabel 2. Hasil Uji Regresi Berganda Coefficientsa

\begin{tabular}{|c|c|c|c|c|c|c|}
\hline \multirow{2}{*}{\multicolumn{2}{|c|}{ Model }} & \multicolumn{2}{|c|}{ Unstandardized Coefficients } & \multirow{2}{*}{$\begin{array}{c}\text { Standardized } \\
\text { Coefficients } \\
\text { Beta }\end{array}$} & \multirow[t]{2}{*}{$\mathrm{t}$} & \multirow[t]{2}{*}{ Sig. } \\
\hline & & B & Std. Error & & & \\
\hline \multirow[t]{3}{*}{1} & (Constant) & -1.551 & 1.159 & & -1.338 & .195 \\
\hline & LN_CR & 1.510 & .683 & .663 & 2.212 & .038 \\
\hline & LN_ד̄ CTA & -.957 & .390 & -.738 & -2.456 & .023 \\
\hline
\end{tabular}




\begin{tabular}{|c|c|c|c|c|c|}
\hline \multirow[t]{2}{*}{ Model } & \multicolumn{2}{|c|}{ Unstandardized Coefficients } & Standardized & $t$ & Sig. \\
\hline & $B$ & Std. Error & Beta & & \\
\hline LN_DER & .339 & .294 & .262 & 1.152 & .262 \\
\hline LN PM & .551 & .251 & .404 & 2.194 & .040 \\
\hline
\end{tabular}

diketahui konstanta sebesar -1.551 menyatakan bahwa jika Current Ratio bernilai nol ( $\left.L N \_C R=0\right)$, Working Capital to Total Assets bernilai nol (LN_WCTA=0), Debt to Equity Ratio bernilai nol (LN_DER=0), dan Profit Margin bernilai nol (LN_PM=0) maka nilai perubahan laba sebesar -1.551. Current Ratio (LN_CR) mempunyai koefisien regresi sebesar 1.510 menyatakan bahwa setiap penambahan $1 \%$ current ratio (LN_CR) (dengan asumsi bahwa nilai koefisien variabel lain tetap atau tidak berubah) maka akan menaikkan perubahan laba sebesar 1.510 . Namun sebaliknya, jika current ratio (LN_CR) turun 1\% (dengan asumsi bahwa nilai koefisien variabel lain tetap atau tidak berubah) maka akan menurunkan perubahan laba sebesar 1.510.

Working Capital to Total Assets (LN_WCTA) mempunyai koefisien regresi sebesar -0.957 menyatakan bahwa setiap penambahan $1 \%$ working capital to total assets (LN_WCTA) (dengan asumsi bahwa nilai koefisien variabel lain tetap atau tidak berubah) maka akan menurunkan perubahan laba sebesar 0.957. Namun sebaliknya, jika working capital to total assets (LN_WCTA) turun 1\% (dengan asumsi bahwa nilai koefisien variabel lain tetap atau tidak berubah) maka perubahan laba diprediksi mengalami peningkatan sebesar 0.957 .

Debt to Equity Ratio (LN_DER) mempunyai koefisien regresi sebesar 0.339 menyatakan bahwa setiap penambahan $1 \%$ debt to equity ratio (LN_DER) (dengan asumsi bahwa nilai koefisien variabel lain tetap atau tidak berubah) maka akan menaikkan perubahan laba sebesar 0.339. Namun sebaliknya, jika debt to equity ratio (LN_DER) turun $1 \%$ (dengan asumsi bahwa nilai koefisien variabel lain tetap atau tidak berubah) maka akan menurunkan perubahan laba sebesar 0.339 .

ProfitMargin (LN_PM) mempunyai koefisien regresi sebesar 0.551 menyatakan bahwa setiap penambahan $1 \%$ profit margin (LN_PM) (dengan asumsi bahwa nilai koefisien variabel lain tetap atau tidak berubah) maka akan menaikkan perubahan laba sebesar 0.551 . Namun sebaliknya, jika profit margin (LN_PM) turun 1\% (dengan asumsi bahwa nilai koefisien variabel lain tetap atau tidak berubah) maka akan menurunkan perubahan laba sebesar 0.551 .

\subsection{Classical Assumption Test Analysis}

\section{a. Normality Test}

The normality test aims to test whether the residual variables are normally distributed. The statistical test that can be used to test whether the residuals are normally distributed is the Kolmogorov-Smirnov (KS) non-parametric statistical test by making a hypothesis.

Table 3. Normality Test Results (1)

One-Sample Kolmogorov-Smirnov Test

\begin{tabular}{ccc}
\hline & & $\begin{array}{c}\text { Unstandardized } \\
\text { Residual }\end{array}$ \\
\hline $\mathrm{N}$ & mean & 55 \\
Normal Parameters, b & Std. Deviation & .0000000 \\
& Absolute & 2.35690295 \\
Most Extreme Differences & Positive & .192 \\
& negative & .192 \\
Kolmogorov-Smirnov Z & & -135 \\
asymp. Sig. (2-tailed) & & 1,427 \\
\hline
\end{tabular}

Source: Data processed by the author

Based on the results of statistical tests using the Kolmogorov-Smirnov model as contained in table 3 , it can be concluded that the data are not normally distributed, this can be seen from the value of Asymp.Sig.(2-tailed) Kolmogorov-Smirnov of 0.034 which is smaller than 0.05 , so data are not normally distributed. To test whether the graphic data for the variables CR, WCTA, DER, and 
PM have a normal distribution or not, it can be done by describing the histogram curve and the Normality Probability Plot graph as follows:

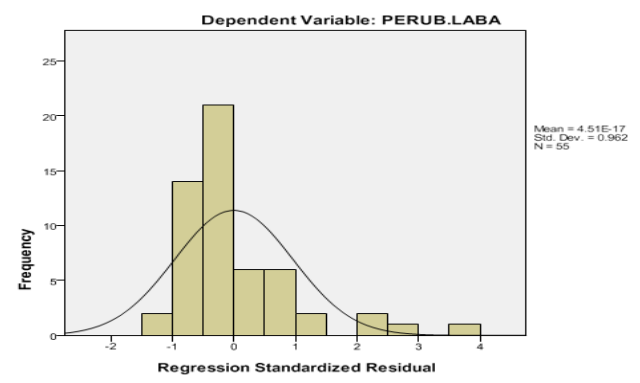

Figure 1. Histogram

From the results of the histogram curve display above, it can be seen that the slope of the curve tends to the right, this indicates that the data is not normally distributed.

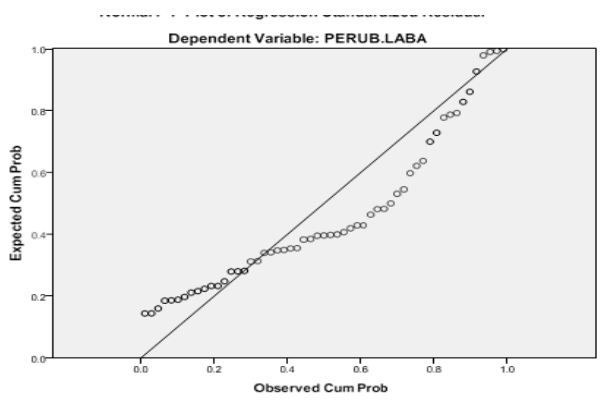

Figure 2. P-Plot Normal Graph

From the results of the Normal P-Plot Regression graph above, it can be seen that the points spread away from the diagonal line which indicates the data is not normally distributed.

To change the residual value so that it is normally distributed, the researcher transforms the data into a natural logarithm (Ln) model. After that, the data was retested based on the assumption of normality. The following are the results of testing with Kolmogorov-Smirnov after the transformation:

Table 4. Normality Test Results (2) After Transformation With Natural Logarithms One-Sample Kolmogorov-Smirnov Test

\begin{tabular}{ccc}
\hline & & $\begin{array}{c}\text { Unstandardized } \\
\text { Residual }\end{array}$ \\
\hline $\mathrm{N}$ & mean & 26 \\
Normal Parameters, b & Std. Deviation & .0000000 \\
& Absolute & 1.05857044 \\
Most Extreme Differences & Positive & .130 \\
& negative & .130 \\
Kolmogorov-Smirnov Z & & -.094 \\
asymp. Sig. (2-tailed) & & .661 \\
\hline
\end{tabular}

Source: Data processed by the author

Table 4 shows that the results of statistical testing using the Kolmogorov-Smirnov model indicate that the data has been normally distributed because the Kolmogorov-Smirnov Asymp.Sig (2-tailed) value of 0.775 is greater than 0.05 . The results of normality testing with histograms and Normal P-Plot Regression Standardized Residual can also be seen in the following figure: 


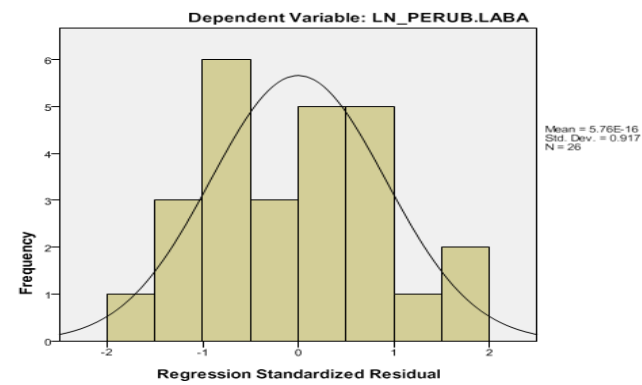

Figure 3. Histogram After Transformation

The histogram graph above shows that the data is normally distributed. This can be seen from the histogram graph which shows the distribution of data following a diagonal line that is neither skewed to the left nor skewed to the right.

\section{b. Multicollinearity Test}

This test is conducted to determine whether the independent variables contain a correlation or not. If the Variance Inflation Factor $(\mathrm{VIF})<10$, then between independent variables (LN_CR, LN_WCTA, LN_DER and LN_PM) there is no multicollinearity. The following are the results of the multicollinearity test:

Table 5. Multicollinearity Test Results Coefficientsa

\begin{tabular}{ccc}
\hline Model & \multicolumn{2}{c}{ Collinearity Statistics } \\
& Tolerance & VIF \\
\hline (Constant) & & \\
LN_CR & .340 & 2,944 \\
LN_WCTA & .338 & 2,955 \\
LN_DER & .588 & 1,701 \\
LN_PM & .898 & 1.113 \\
\hline Source: Data processed by the author
\end{tabular}

From the results of table 5 above, it is known that the Variance Inflation Factor (VIF) value of LN_CR (Current Ratio) is 2,944, LN_WCTA (Working Capital to Total Assets) is 2,955, LN_DER (Debt to Equity Ratio) is 1,701 , and LN_PM (Profit Margin) amounted to 1,113 . The VIF value for all independent variables is still smaller than $10(\mathrm{VIF}<10)$. So it can be concluded that the four independent variables of this study do not occur multicollinearity.

\section{c. Heteroscedasticity Test}

The heteroscedasticity test aims to test whether there is an inequality of variance from the residuals of one observation to another in the regression model. A good regression model is that there is no heteroscedasticity or homoscedasticity. In the regression model, it is stated that heteroscedasticity has occurred if the existing points form a certain regular pattern. In the regression model, there is no heteroscedasticity if the points do not form a certain regular pattern and the points spread above and below zero on the $Y$ axis.

The following is attached a scatterplot graph to analyze whether there is heteroscedasticity by observing the spread of the points in the image. 


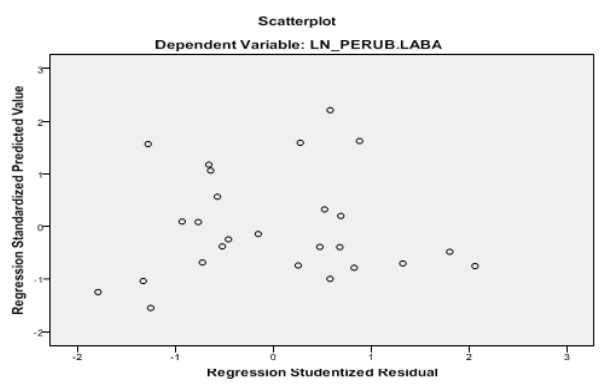

Figure 4. Heteroscedasticity Test Results

\section{d. Autocorrelation Test}

Autocorrelation test is used to determine whether there is a correlation between sample members sorted by time. The diagnosis of autocorrelation was carried out through testing the value of the Durbin Watson test (DW test). If the Durbin Watson (DW) test value shows the number 1.65 to 2.35 then there is no autocorrelation. The following are the results of the autocorrelation test:

From the results of the autocorrelation test table, it is known that the Durbin Watson (DW) value is 2.299. This number is between 1.65 to 2.35 , so there is no autocorrelation.

Table 6. Autocorrelation Test Results Model Summaryb

\begin{tabular}{cccccc}
\hline Model & $\mathrm{R}$ & $\mathrm{R}$ Square & $\begin{array}{c}\text { Adjusted } \mathrm{R} \\
\text { Square }\end{array}$ & $\begin{array}{c}\text { Std. Error of the } \\
\text { Estimate }\end{array}$ & Durbin-Watson \\
\hline 1 & $.599 \mathrm{a}$ & .359 & .237 & 1.15500 & 2.299 \\
\hline
\end{tabular}

\section{CONCLUSION}

Simultaneously, the results of this study indicate that there is an influence between the variables current ratio, working capital to total assets, debt to equity ratio and profit margin on changes in profit. This may be because the sampled companies can use and utilize their assets appropriately and efficiently in generating profits and have good company performance. The results of simultaneous hypothesis testing can be seen in table 6 . Partially, the profit margin variable has a sig nificant and positive effect on changes in profit.

\section{REFERENCES}

Brigham, Eugene F. dan Joel F. Houston, 2006. Dasar- dasar Manajemen Keuangan, Buku Satu, Edisi Kesepuluh, Alih Bahasa Ali Akbar Yulianto, Salemba Empat, Jakarta.

Damanik, Eko Bastian, 2010. "Pengaruh Rasio Keuangan Terhadap Perubahan Laba Pada Perusahaan Manufaktur Sektor Industri Barang Konsumen Yang Terdaftar di Bursa Efek Indonesia". Skripsi, Program Studi Strata Satu Akuntansi Fakultas Ekonomi Universitas Sumatera Utara.

Dewanti, Hestina Wahyu, 2009. "Analisis Pengaruh Perubahan NPM, LDR, NPL dan BOPO Terhadap Perubahan Laba (Studi Pada Bank Devisa dan Bank Non Devisa Periode Juni 2004 - Juni 2007)". Tesis, Program Studi Magister Manajemen Program Pasca Sarjana Universitas Diponegoro.

Erlina, 2008. Metodologi Penelitian Bisnis untuk Akuntansi dan Manajemen, Edisi Kedua. Medan: USU Press. Harahap, Sofyan Syafri, 2000. Teori Akuntansi. Raja Grafindo Persada, Jakarta.

2006. Analisis Kritis Atas Laporan Keuangan, Edisi Pertama, Raja Grafindo Persada, Jakarta.

Horne, James C. Van dan John M. Wachowicz, Jr, 2005. Prinsip - prinsip Manajemen Keuangan, Buku Satu, Edisi Kedua Belas, Alih Bahasa oleh Dewi Fitriasari dan Deny Arnos Kwary, Salemba Empat, Jakarta.

Indonesia Stock Exchange, 2011. laporan keuangan/detail/ soft copy laporan keuangan. www.idx.co.id Ikatan Akuntan Indonesia, 2007. Standar Akuntansi Keuangan, Penerbit Salemba Empat, Jakarta.

Jurusan Akuntansi, Fakultas Ekonomi Universitas Sumatera Utara, 2004. Buku Petunjuk Teknis Penulisan Proposal Penelitian dan Penulisan Skripsi, Medan.

Kasmir, 2009. Analisis Laporan Keuangan, Penerbit Rajawali Pers, Jakarta. 
Meriewaty, Dian. dan Setyani, Astuti Yuli, 2005. "Analisis Rasio Keuangan terhadap Perubahan Kinerja pada Perusahaan di Industri Food and Beverages yang Terdaftar di BEJ", Simposium Nasional Akuntansi VIII, 15-16 September, hal. 277-287.

Munawir, S., 2004. Analisa Laporan Keuangan, Edisi Keempat, Penerbit Liberty, Yogyakarta.

Pakpahan, Roselina, 2011. "Pengaruh Rasio Keuangan Terhadap Perubahan Laba Pada Perusahaan Otomotif Yang Terdaftar di Bursa Efek Indonesia". Skripsi, Program Studi Strata Satu Akuntansi Fakultas Ekonomi Universitas Sumatera Utara.

Sugiyono, 2004. Metode Penelitian Bisnis, Cetakan Kesembilan, Alfabeta, Bandung. 2006. Statistika Untuk Penelitian, Cetakan Kesembilan, Alfabeta, Bandung.

Sarifudin, Muhamad, 2005. "Analisis Pengaruh Rasio-rasio Keuangan Terhadap Perubahan Laba (Studi Empiris: Pada Industri Perbankan Yang Listed di BEJ)". Masters thesis, Program Pasca Sarjana Universitas Diponegoro.

Stice, Earl K., James D. Stice, dan K. Fred Skousen, 2004. Akuntansi Intermediate, Buku Satu, Edisi Kelima Belas, Alih Bahasa Safrida R. Parulian dan Ahmad Maulana, Salemaba, Empat Jakarta.

Wild, John J., K.R. Subramanyam, dan Robert F. Halsey, 2005. Financial Statement Analysis, Alih Bahasa Yanivi S.Bachtiar, S.Nurwahyu Harahap, Analisis Laporan Keuangan, Edisi Delapan, Buku Satu, PT Salemba Empat: Jakarta.

Zul, Eka Khairunnisa, 2009, "Pengaruh Rasio Keuangan Terhadap Perubahan Laba Pada Perusahaan Manufaktur Yang Terdaftar di Bursa Efek Indonesia”. Tesis, Sekolah Pasca Sarjana Universitas Sumatera Utara. 